\title{
Effective management of COPD in primary care - the role of long-acting beta agonist/inhaled corticosteroid combination therapy
}

\author{
C.P. (Onno) van Schayck ${ }^{\mathrm{a}, *}$, Jim Reid ${ }^{\mathrm{b}}$
}

\author{
a Department of General Practice, University of Maastricht Research Institute CAPHRI, P.O. Box 616, \\ 6200 MD Maastricht, The Netherlands \\ b Dunedin School of Medicine, University of Otago, Dunedin, New Zealand
}

Received 3 June 2005; accepted 22 February 2006

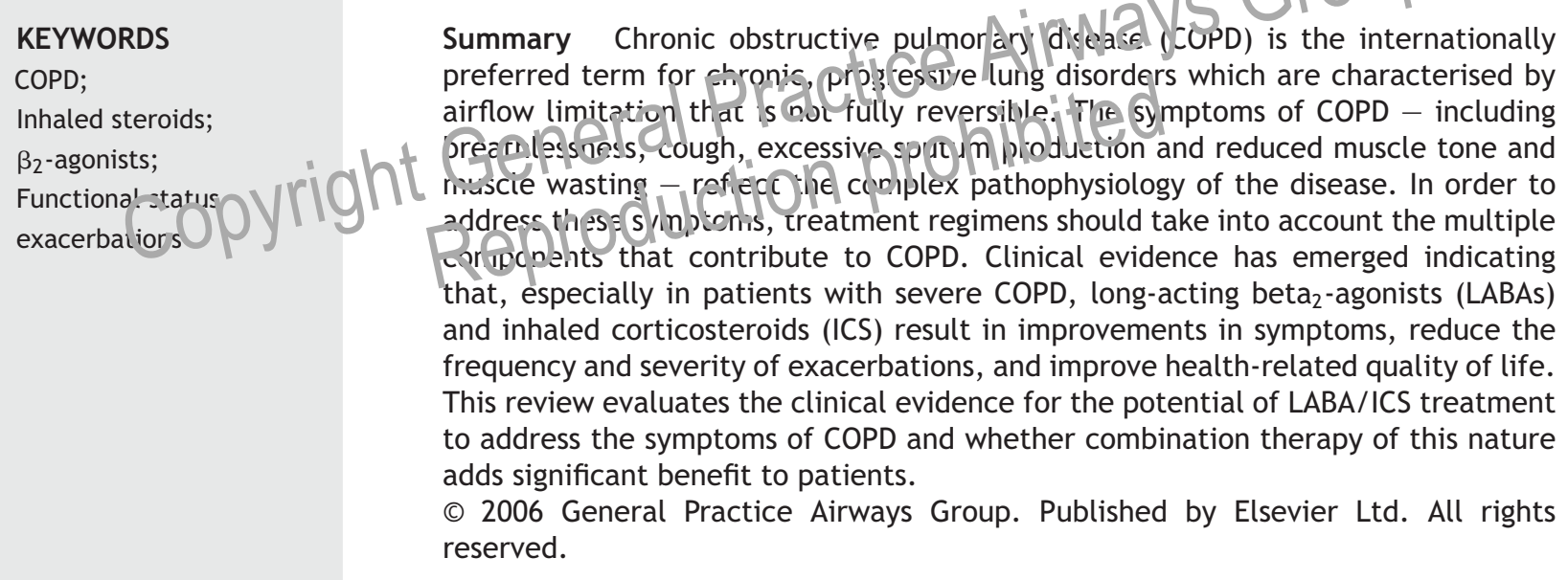

\section{Contents}

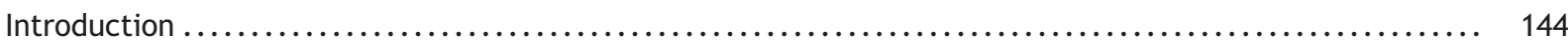

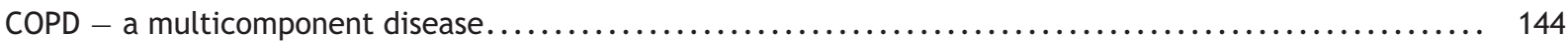

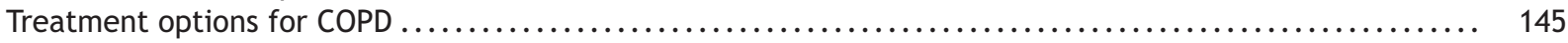

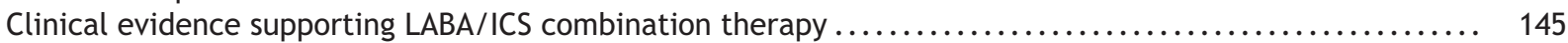

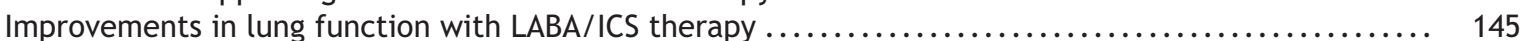

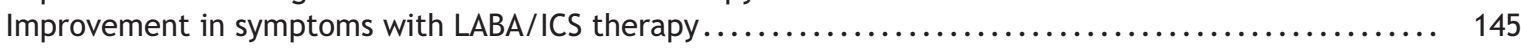

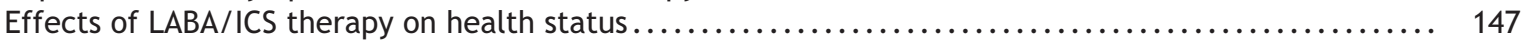

\footnotetext{
* Corresponding author. Tel.: +31 43 3882152; fax: +31 433619344 .

E-mail address: onno.vanschayck@hag.unimaas.nl (C.P.(O.) van Schayck).
} 


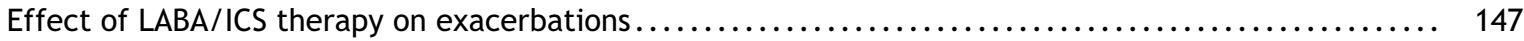

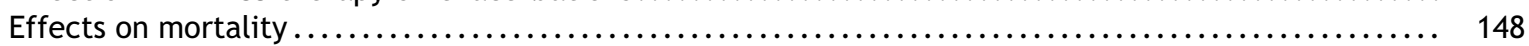

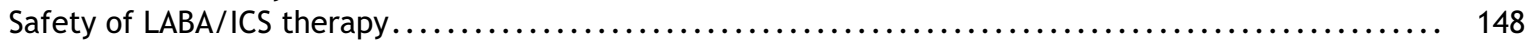

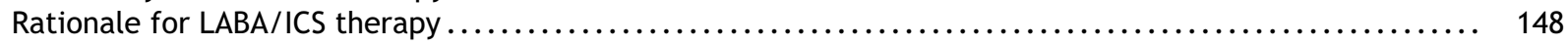

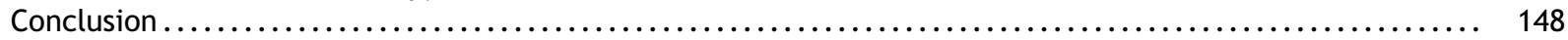

References....................................................................... 149

\section{Introduction}

Chronic obstructive pulmonary disease (COPD) encompasses several commonly used pathological and clinical labels, including emphysema and chronic bronchitis, both of which may be present to a greater or lesser degree in patients with the disease [1-3]. Although patients with COPD show progressive reduction in lung function (as measured by spirometry) they may be asymptomatic in the early stages of the disease. Indeed, many patients will not consult a physician until their lung function has significantly declined. Patients typically present with symptoms such as chronic cough, sputum production and breathlessness upon exertion, which are indicative of moderate to severe COPD. In addition, symptoms relating to the systemic component of the disease, such as muscle wasting and loss of appetite, are? commonly seen in severe COPD As Ahe disease progresses, patients experier, a decline tin their heattin itas. Tine worsening of y yptons, especialiy breathilessness, n av of en $\in$ ne them from exercising and from carrying out daily activities such as walking or climbing stairs, and it is often this reduction in their quality of life that prompts many patients to seek medical attention. One of the key features of COPD is the occurrence of acute exacerbations of symptoms which may lead to respiratory failure and, in severe cases, death [4,5]; these are thought to occur in response to lung infections and possibly airborne pollutants such as cigarette smoke, and in some countries pollution from cooking on open fires.

\section{COPD - a multicomponent disease}

It is now accepted that COPD is a multicomponent disease with airway inflammation at its core comprising airway structural changes and mucociliary dysfunction, all leading to airflow limitation (see Figure 1) $[2,6,7]$. The components of COPD are closely interrelated in what has been termed the 'vicious cycle of COPD' [7].

Indeed, the symptoms of COPD reflect the multiple component nature of the disease. Airflow limitation, manifested by shortness of breath particularly upon exertion, is progressive, only partly reversible, and is to some extent due to inappropriate smooth muscle contraction. Many of the structural changes surin as obs of alveolar airspaces, pulmonaily Soscular changes [8] and increased s:npotn muscle mass [9] which are also assoclated with airflow limitation in COPD are a result of darloge 60 the lungs caused by prolonged ail ily Oinflammation. Patients with COPD may also exhibit excess mucus secretion and reduced mucociliary clearance, leading to a build-up of mucus in the lungs, which may be expelled on coughing $[10,11]$. The systemic component of COPD is less well understood, but is thought to be heavily associated with inflammatory mediators, and may involve various organs including skeletal muscle, the central nervous system, and the cardiovascular system [6].

This review will summarise the treatment options for COPD and evaluate the clinical benefit of combination treatment with long-acting beta ${ }_{2}$ agonists (LABAs) and inhaled corticosteroids (ICS), in a single inhaler.

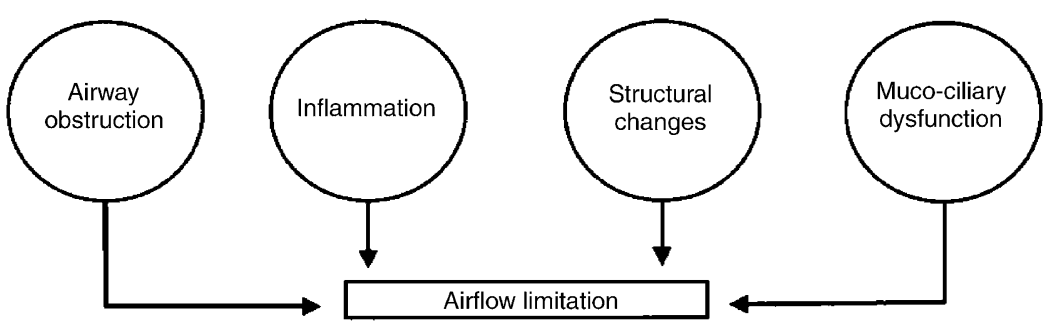

Figure 1 The multiple components contributing to airflow limitation in COPD. 


\section{Treatment options for COPD}

The most important risk factor for COPD in the Western world is smoking. Smoking cessation is essential for the treatment of any patient with COPD, since patients who continue to smoke show disease progression which is twice as rapid compared to those who give up [12]. However, smoking cessation is difficult to achieve and even more difficult to sustain in COPD [13].

Physical therapies for COPD, such as pulmonary rehabilitation programmes, are effective on exercise tolerance and health status in patients with moderate to severe COPD and to some extent in patients with mild to moderate disease [14].

There are currently no pharmacological therapies that unequivocally slow the decline in lung function seen in COPD [15]. However, many drugs, including long-acting anticholinergics, long-acting beta ${ }_{2}$-agonists (LABAs), and inhaled corticosteriods (ICS), have positive effects on some of the key symptoms of COPD including improvements in cough and breathlessness, exacerbations, and lung function.

Bronchodilators are a mainstay of COPD treatment through their ability to work by both smooth and non-smooth muscle mechanisms. The long-acting muscarinic reseptor arcescunist tiotropium has been shown sigr ific at tly is improve lung function, tis'scr $0 \equiv a$, lexercise tolerande, and health related quality of life ir Daments vilinCOPD, relative to placebo [16-18]. The two currently available LABAs - salmeterol and formoterol - also show significant improvements in lung function, health status, and symptom reduction, compared with both placebo [19-22] and ipratropium $[23,24]$.

LABAs are recommended for use in patients with moderate-to-severe COPD [25] and those with 'persistent symptoms' [26]. Twice-daily dosing of LABAs (i.e. salmeterol, formoterol) is more convenient than 4-times-daily regimens of traditional short-acting bronchodilators [27]. In clinical studies significant improvements in lung function, exacerbation rates, and health status have been demonstrated with LABAs in moderate to severe COPD $[28,29]$.

The role of ICS therapy in COPD has been the subject of much debate [30-32]. However, ICS are recommended for regular treatment in COPD patients with more severe disease and frequent exacerbations $[25,26]$. Some studies showed clinical benefits with ICS use in moderate to severe but not in mild COPD [33-36]. ICS use is associated with reductions in the number and severity of exacerbations experienced by patients with severe COPD [34,36-39]. In addition, in a pooled analysis of seven randomised studies involving 5085 patients, inhaled corticosteroids reduced all-cause mortality by $\sim 25 \%$ relative to placebo in patients with stable COPD [40].

\section{Clinical evidence supporting LABA/ICS combination therapy}

The beneficial effects of LABA/ICS combination therapy have been recognised by guidelineforming bodies $[25,26]$. These recommendations have been based on a number of long-term ( $\geq 6$ months) randomised, double-blind, placebocontrolled, parallel group trials assessing the efficacy and safety of combining a LABA with an ICS in a single inhaler $[29,37-39,41-43]$. Outcome measures in these trials included lung function, symptom scores, exacerbation rates, quality of life, and safety and tolerability. Results from these trials are seen in Table 1.

\section{Improvements in lung fonction with LABA/ICS thainip a}

A progressive dectine (in lung function that is not fully reersiple and which results in increased shortness of breath, is the hallmark of COPD. Measurement of lung function is critical in order to assess the severity of the disease in individual patients, and helps to predict prognosis. The parameter used is the forced expiratory volume in one second $\left(\mathrm{FEV}_{1}\right)$, with lower levels associated with more advanced disease and a poorer prognosis.

LABA/ICS combination treatment is associated with improvements in lung function, compared with monotherapy, in severe COPD $[29,37-39,41]$. Studies show pre-dose $\mathrm{FEV}_{1}$ is improved by $13-17 \%$ over baseline by LABA/ICS treatment and can significantly increase pre-dose and post-dose $\mathrm{FEV}_{1}$ compared with ICS monotherapy (Table 1) [29,37-39,41]. In patients taking LABA/ICS combination therapy, the withdrawal of ICS therapy is associated with a significant, acute, and persistent deterioration in lung function [44].

\section{Improvement in symptoms with LABA/ICS therapy}

The main symptoms of COPD that prompt patients to seek medical attention are breathlessness and 
Table 1 Long-term, randomised, double-blind, placebo-controlled, parallel group trials of LABA/ICS combination treatment in COPD

\begin{tabular}{|c|c|c|c|c|c|c|c|}
\hline \multirow[t]{2}{*}{ Study } & \multirow[t]{2}{*}{ Combination treatment ARM } & \multirow{2}{*}{$\begin{array}{l}\text { Length } \\
\text { (weeks) }\end{array}$} & \multirow{2}{*}{$\begin{array}{l}\text { Severity (number } \\
\text { randomized) }\end{array}$} & \multicolumn{4}{|c|}{ LABA/ICS treatment: Results at endpoint } \\
\hline & & & & $\mathrm{FEV}_{1}$ & Symptoms & $\begin{array}{l}\text { Rate of exacerbations } \\
\text { (\% reduction) }\end{array}$ & HRQoL \\
\hline $\begin{array}{l}\text { Tristan, } 2003 \\
\text { [37] }\end{array}$ & $\begin{array}{l}\text { Salmeterol }(50 \mathrm{mcg}) / \text { fluticasone } \\
\text { propionate }(500 \mathrm{mcg} \text { bid })\end{array}$ & 52 & $\begin{array}{l}\text { Moderate-to-severe } \\
(N=1465)\end{array}$ & $+10 \%$ vs baseline $e^{b, c, d}$ & $\begin{array}{l}\text { Breathlessness }{ }^{\mathrm{b}, \mathrm{c}, \mathrm{d}} \\
\text { Use of relief medication } \\
\text { Cough }^{\mathrm{b}, c, \mathrm{~d}} \\
\text { Night-time awakenings } \\
\text {, }, \mathrm{c}\end{array}$ & $\begin{array}{l}25 \text { vs baseline }{ }^{\mathrm{b}} \\
30 \text { in patients } \mathrm{FEV}_{1}<50 \%\end{array}$ & SGRQ: -4.5 vs baseline $e^{b, d}$ \\
\hline $\begin{array}{l}\text { Dal Negro et al., } \\
2003 \text { [41] }\end{array}$ & $\begin{array}{l}\text { Salmeterol }(50 \mathrm{mcg}) / \text { fluticasone } \\
\text { propionate }(250 \mathrm{mcg}) \text { bid }\end{array}$ & 52 & Moderate $(N=18)$ & $+7.3 \%$ vs baseline ${ }^{\mathrm{b}}$ & $\begin{array}{l}\text { Only combination therapy had } \\
\text { significantly greater symptom } \\
\text { score reduction }\end{array}$ & $\begin{array}{l}34 \text { vs baseline (only } \\
\text { combir a a n therapy had a } \\
\text { s gritic.r treduction) }\end{array}$ & - \\
\hline $\begin{array}{l}\text { Hanania, } 2003 \\
\text { [40] }\end{array}$ & $\begin{array}{l}\text { Salmeterol }(50 \mathrm{mcg}) / \text { fluticasone } \\
\text { propionate }(250 \mathrm{mcg}) \text { bid }\end{array}$ & 24 & $\begin{array}{l}\text { Moderate-to-severe } \\
(N=723)\end{array}$ & $+16.6 \%$ vs baseline ${ }^{b, c}$ & Breat'nlessre:s & & CRDQ: +10.0 vs baseline ${ }^{\mathrm{b}}$ \\
\hline $\begin{array}{l}\text { Mahler et al., } \\
2002[29]\end{array}$ & $\begin{array}{l}\text { Salmeterol } 50 \mathrm{mcg}) / \text { fluticasone } \\
\text { propionate }(500 \mathrm{mcg}) \text { bid }\end{array}$ & 24 & & & 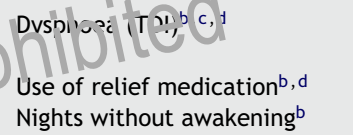 & - & CRDQ: +10.0 vs baseline $e^{b, d}$ \\
\hline $\begin{array}{l}\text { Calverley et al., } \\
2003 \text { [38] }\end{array}$ & $\begin{array}{l}\text { Formoterol }(9 \mathrm{mcg}) \text { ivudesolide } \\
(320 \mathrm{mcg}) \text { bid }\end{array}$ & 52 & $\begin{array}{l}R d \in \text { at } t-t) \text {-severe } \\
(v=1022)\end{array}$ & $+14 \%$ vs placebo $o^{b, c, d}$ & $\begin{array}{l}\text { Symptom score }^{\mathrm{b}} \\
\text { Breathlessness }^{\mathrm{b}, \mathrm{d}} \\
\text { Chest tightness }^{\mathrm{b}} \\
\text { Night-time awakenings }\end{array}$ & 23.6 vs placebo $o^{b, c}$ & $\begin{array}{l}\text { SGRQ total score: }-7.5 \text { vs } \\
\text { placebo }, c, d\end{array}$ \\
\hline $\begin{array}{l}\text { Szafranski et al., } \\
2003[39]\end{array}$ & $\begin{array}{l}\text { Formoterol }(4.5 \mathrm{mcg}) / \text { budesonide } \\
(160 \mathrm{mcg}) \text { bid }\end{array}$ & 52 & $\begin{array}{l}\text { Moderate-to-severe } \\
(N=812)\end{array}$ & $+15 \%$ vs placebo $o^{b, d}$ & $\begin{array}{l}\text { Total symptom score }{ }^{b, d} \\
\text { Breathlessness } \\
\text { Cough }^{b, d}\end{array}$ & $\begin{array}{l}24 \text { vs placebo (severe) } \\
62 \text { vs placebo }(\text { mild })^{\mathrm{b}, c, \mathrm{~d}}\end{array}$ & $\begin{array}{l}\text { SGRQ total score: }-3.9 \text { vs } \\
\text { baseline }{ }^{\text {b }}\end{array}$ \\
\hline $\begin{array}{l}\mathrm{FEV}_{1} \text { : forced ex } \\
\text { index; CRDQ: } \mathrm{Cl} \\
\text { a All studies } \\
\text { b Significant } \\
\text { c Significant } \\
\text { d Significant }\end{array}$ & $\begin{array}{l}\text { piratory volume in one second } \\
\text { rronic Respiratory Disease Ques } \\
\text { compared LABA/ICS combinatio } \\
\text { mprovement with LABA/ICS th } \\
\text { mprovement with LABA/ICS th } \\
\text { mprovement with LABA/ICS th }\end{array}$ & $\begin{array}{l}\text { SRQ: St } \\
\text { nnaire }\end{array}$ & $\begin{array}{l}\text { th with LABA mon } \\
\text { pared with placeb } \\
\text { pared with LABA n }\end{array}$ & $\begin{array}{l}\text { Dy, ICS monother } \\
\text { erapy. }\end{array}$ & $\begin{array}{l}\text { ve score indicates an improv } \\
\text { and placebo. }\end{array}$ & ement in health status); & DI: transitional dyspnoea \\
\hline
\end{tabular}


cough. Exercise is a key component of effective treatment for COPD [25], and yet, due to increasing breathlessness as the disease progresses, many patients may find even walking or climbing stairs difficult. LABA/ICS combination therapy can produce a clinically significant reduction in these and other daily symptoms of severe COPD (Table 1) [29,37-39,41-43].

Four studies have demonstrated that LABA/ICS combination therapy significantly reduces breathlessness scores compared with monotherapy [29,37-39]. Significant improvements were consistently seen within one week of initiating treatment and maintained until the study end. In patients taking LABA/ICS combination therapy, the withdrawal of ICS therapy is associated with a significant, acute and persistent deterioration in dyspnoea [44]. In addition, combination LABA/ICS therapy produces a significantly greater improvement in the transition dyspnoea index (TDI) in patients treated with an anti-cholinergic/shortacting beta agonist combination (Combivent) $[45,46]$.

In studies that reported cough scores, LABA/ICS treatment demonstrated a trend towards an improvement in cough scores compared with monotherapy [37-39,43] (Table 1). This trend was significant compared with ICS and I.ATA monotherapy within two weoks ff intidtirg

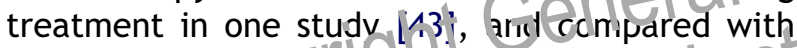
ICS after 12 month/ il Griother study [39]. Cocigh improved sisrinicanty in the LABAAC(S) Conibination therapy group, but not in the $\mathrm{IS}$ monotherapy or LABA monotherapy groups in one study [37].

Improvements have been demonstrated in chest tightness and night-time awakenings with formoterol/budesonide therapy and these were significant compared with budesonide alone $[38,39]$. A significant reduction in the use of relief medications has been demonstrated with salmeterol/fluticasone propionate compared with fluticasone propionate monotherapy [29,37, 41] and salmeterol monotherapy [37] and in the number of night-time awakenings compared with fluticasone propionate monotherapy $[37,41]$.

\section{Effects of LABA/ICS therapy on health status}

Health status is generally assessed using a questionnaire such as the St George's Respiratory Questionnaire (SGRQ), which takes into account symptoms, activity and impact on the daily life of patients, and in which a change of 4 points from baseline is considered clinically relevant
[47]. Another commonly used questionnaire is the Chronic Respiratory Disease Questionnaire (CRDQ), which evaluates breathlessness, fatigue, emotional function and the patient's feeling of control over the disease, in which a change of 10 points from baseline is considered clinically meaningful $[48,49]$.

In studies using the CRDQ, only one study with GABA/ICS combination in severe COPD showed a statistically significant rise in CRDQ compared with ICS alone (+4.8; $p=0.017)$ [29].

Studies using the SGRQ have also shown clinically significant $(\geq 4)$ improvements sustained over baseline in severe COPD [37-39]. These improvements, seen in patients receiving LABA/ICS combination therapy, are significantly greater than those seen in patients receiving either LABA or ICS monotherapy $[37,39]$.

In addition, studies show that patients on combination treatment have greater improvements in limitation of activity scores, indicating that combination therapy allows patients with severe COPD to lead a more active life compared with patients receiving either LABA or ICS monotherapy $[29,38,41]$.

\section{Effect of $L A N A M$ inerapy on exacerbations}

Exacerbations are os oriated with an increase in symitoms that cause the patient to seek medical atterition, and patients may require hospitalisation and/or oral corticosteroid treatment for exacerbations $[4,5,50]$. Exacerbations are also associated with significant mortality and morbidity [51-53]. In addition, recent data from prospective studies show that exacerbation frequency contributes to the decline in lung function in patients with COPD [54]. A decrease in exacerbation frequency is also strongly associated with an increase in patient health status. Therefore, exacerbations have a significant negative effect on the morbidity and mortality of patients with COPD, and controlling exacerbation frequency should be a major goal of COPD management $[2,55]$.

LABA/ICS combination therapy is associated with a significant reduction in exacerbation rates in severe COPD [37,39,42] (Table 1), reducing the rate of exacerbations requiring oral corticosteroids by up to $24-35 \%[37,39]$. LABA/ICS combination treatment showed a trend towards a greater reduction in exacerbations requiring oral corticosteroids, with a significant change compared to LABA monotherapy in two studies [38,39], and compared to ICS monotherapy in one study [39]. In patients taking LABA/ICS combination therapy, 
the withdrawal of ICS therapy is associated with an increase in mild exacerbations [44].

These reductions in exacerbation rates are likely to be related to the severity of disease and the frequency of exacerbations in individual patients; indeed, it was noted in one study that patients with an $\mathrm{FEV}_{1}<50 \%$ predicted had more than double the time to a first exacerbation [38].

\section{Effects on mortality}

Improving survival is a key unmet need in COPD, and definitive evidence of the effects of pharmacotherapy from a prospective randomised controlled trial is awaited. Morbidity and mortality rate reductions with LABA/ICS treatment have been suggested by epidemiological and observational studies, though these data may be subject to bias and await clarification [56-58]. An ongoing, three-year prospective study in over 6000 patients with COPD, comparing the effects of combination LABA/ICS with placebo and individual LABA and ICS components on morbidity and mortality, will be critical in determining the long-term effects of LABA/ICS [59].

\section{Safety of LABA/ICS therapy}

Although the above evidence cloanly auggest a trend of additional iricrentental venefit with LABA/ICS cortibinted treacrnent, any discilss on d the use of LADA ICS treatmentorictics has to be weighed against the real risk of systemic sideeffects.

Minor adverse events such as throat irritation and oral candidiasis are seen with ICS monotherapy. More serious adverse events due to systemic absorption of corticosteroids are rare. Significant but small decreases in mean cortisol are seen, but these are not associated with evidence of hypoadrenalism [34,36].

There is a concern that ICS therapy may be associated with an increased risk of bone mineral density (BMD) reduction, or fracture. The Lung Health Study II, which looked at the safety and efficacy of triamcinolone acetonide $(600 \mathrm{mcg}$ bid) over 3 years, reported a $2 \%$ reduction in BMD in the femoral neck with triamcinolone, compared with placebo [60]. A population-based casecontrol study in the UK suggested a dose-response relationship between ICS use and hip fractures, even after adjustment for oral corticosteroids [61]. However, other studies and most major analyses of published data suggest ICS therapy is not associated with an increased risk of bone mineral density reduction or fracture [62-64].
LABA monotherapy is generally thought to be well tolerated; however, tremor and cardiac effects can be a problem. Studies with salmeterol and formoterol in patients with COPD do not report increased risk of cardiovascular adverse events $[65,66]$.

In the large number of clinical studies with LABA/ICS combination therapy, the incidence of patients reporting adverse events is similar in patients receiving LABA/ICS combination therapy and in those receiving monotherapy with a LABA or an ICS [29,37-39,41,42].

\section{Rationale for LABA/ICS therapy}

When combining therapies, the effects of potentially complex dosing regimens on patient compliance should be considered. The ability to deliver multiple drugs using a single device has important implications for COPD treatment, since simpler treatment regimens are associated with higher patient compliance and better outcomes [67]. However, there may be additional benefits from the co-administration of $t$ hesecurigs.

Many current Hespies target just one aspect of the complex patnophysiology of COPD. For optimal treatment, a therapeutic regimen that has the potertic t $p$ act crimultiple underlying components of the cuisease might be considered.

Treatment with ICS has not shown conclusive evidence or consistent effects on the inflammatory processes thought to be important in the pathophysiology of COPD. Some consider COPD to be a "steroid-resistant disease" and studies in patients with COPD have shown that even high doses of inhaled corticosteroids do not reduce inflammatory cell numbers, concentrations of cytokines, or proteases [30].

The combination of a LABA with an ICS has the potential to address many underlying components especially in severe COPD. However, COPD is a complex disease and many observations require full confirmation in studies on COPD patients.

\section{Conclusion}

For optimal treatment of COPD, there are indications which support the concept of addressing the underlying multicomponent nature of the disease. This can be achieved by combining treatments with complementary modes of action. In patients with COPD, LABA/ICS therapy has the potential to address multiple 
components contributing to airflow limitation, and therefore the clinical symptoms of the disease. However, further clinical evidence is needed to confirm the extent of these effects. Data from randomised, controlled clinical trials in severe COPD patients show that combination LABA/ICS therapy brings about a rapid improvement in lung function which is sustained for at least 12 months. In addition, greater improvements in the symptoms of cough and breathlessness are seen with combination treatment, compared to monotherapy with the individual agents alone. Importantly, the number and severity of exacerbations experienced by patients is reduced by LABA/ICS combination therapy, compared with monotherapy, in severe COPD. However, in patients with mild to moderate COPD, no additional benefit of LABA/ICS combination thereapy has been shown thus far. Moreover, there are concerns about the increased risk of side-effects and cost of using LABA/ICS therapy in COPD.

\section{References}

[1] BTS. British Thoracic Society. The British Guidelines on Asthma Management 1995: review and position statement. Thorax 1997;55:S1-S21.

[2] GOLD. Global initiative for chronic obstruction lu is
disease: global strategy for the dia nosis prevention of chronic obstr totive pul ribiary disease. Am Respir C.rie foreived ?CC1;163:1256-76.

[3] Snider (iL. Lo il ing chronic obstruc ive futnonar, disease. In: Calverley P, Pride N, editors. En onic Obstructive Pulmonary Disease. London: Chapman and Hall; 1995.

[4] Rodriguez-Roisin R. Pulmonary gas exchange in acute respiratory failure. Eur J Anaesthesiol 1994;11:5-13.

[5] Wedzicha JA. Exacerbations: etiology and pathophysiologic mechanisms. Chest 2002;121:136S-41S.

[6] Agusti AG, Noguera A, Sauleda J, Sala E, Pons J, Busquets X. Systemic effects of chronic obstructive pulmonary disease. Eur Respir J 2003;21:347-60.

[7] Agusti AG. COPD, a multicomponent disease: implications for management. Respir Med 2005;99:670-82.

[8] Wright JL, Lawson L, Pare PD, et al. The structure and function of the pulmonary vasculature in mild chronic obstructive pulmonary disease. The effect of oxygen and exercise. Am Rev Respir Dis 1983;128:702-7.

[9] Cosio MG, Majo J, Cosio MG. Inflammation of the airways and lung parenchyma in COPD: role of $T$ cells. Chest 2002;121:160S-5S.

[10] Rogers DF. Mucus hypersecretion in chronic obstructive pulmonary disease. Novartis Found Symp 2001;234:65-77, discussion 77-83.

[11] Smaldone GC, Foster WM, O’Riordan TG, Messina MS, Perry RJ, Langenback EG. Regional impairment of mucociliary clearance in chronic obstructive pulmonary disease. Chest 1993;103:1390-6.

[12] Anthonisen NR, Connett JE, Kiley JP, et al. Effects of smoking intervention and the use of an inhaled anticholinergic bronchodilator on the rate of decline of FEV1. The Lung Health Study. JAMA 1994;272:1497-505.
[13] Wagena EJ, Knipschild P, Huibers MJH, Wouters EFM Schayck CP van. The efficacy of bupropion and notriptyline for smoking cessation among people who are at risk for or have COPD: a randomized, placebo-controlled trial. Arch Intern Med 2005;165:2286-92.

[14] Chavannes N, Vollenberg JJ, van Schayck CP, Wouters EF. Effects of physical activity in mild to moderate COPD: a systematic review. Br J Gen Pract 2002;52:574-8.

[15] Decramer M, Gosselink R, Bartsch P, et al. Effect of treatments on the progression of COPD: report of a workshop held in Leuven, 11-12 March 2004. Thorax 2005;60:343-9.

[16] Casaburi R, Mahler DA, Jones PW, et al. A longterm evaluation of once-daily inhaled tiotropium in chronic obstructive pulmonary disease. Eur Respir J 2002;19:217-24.

[17] O'Donnell DE, Fluge T, Gerken F, et al. Effects of tiotropium on lung hyperinflation, dyspnoea and exercise tolerance in COPD. Eur Respir J 2004;23:832-40.

[18] Vincken W, van Noord JA, Greefhorst AP, et al. Improved health outcomes in patients with COPD during $1 \mathrm{yr}$ 's treatment with tiotropium. Eur Respir J 2002;19:209-16.

[19] Boyd G, Morice AH, Pounsford JC, Siebert M, Peslis N, Crawford C. An evaluation of salmeterol in the treatment of chronic obstructive pulmonary disease (COPD). Eur Respir J 1997; 10:815-21.

[20] Ramirez-Venegas A, Ward J, Lentine T, Mahler DA. Salmeterol reduces dyspnea and improves lung function in patients with COPD. Chest 1997;112:336-40.

[21] Cazzola M, Matera MG, Santang $10 \mathrm{C}$, Vh is Le ra A, Rossi F, D’Amato G. Salmeteróland formucerol in partially reversible teve thic nic ubstructive pulmonary disease: a do e-- esponse study. Respir Med 1995;89:357-62.

122] Aalbers R, Ayres 4 Fecker V, et al. Formoterol in patients with chrcnic c b: tructive pulmonary disease: a randomized, (or trclled, 3-month trial. Eur Respir J 2002;19:936-43.

[23] Nahler DA, Donohue JF, Barbee RA, et al. Efficacy of salmeterol xinafoate in the treatment of COPD. Chest 1999;115:957-65.

[24] Dahl R, Greefhorst LA, Nowak D, et al. Inhaled formoterol dry powder versus ipratropium bromide in chronic obstructive pulmonary disease. Am J Respir Crit Care Med 2001;164:778-84.

[25] GOLD. Global strategy for the diagnosis management and prevention of chronic obstructive pulmonary disease, Updated 2004. National Institutes of Health. National Heart, Lung and Blood Institute 2004: www.goldcopd.com.

[26] Celli BR, MacNee W. Standards for the diagnosis and treatment of patients with COPD: a summary of the ATS/ERS position paper. Eur Respir J 2004;23:932-46.

[27] Dougherty JA, Didur BL, Aboussouan LS. Long-acting inhaled beta 2-agonists for stable COPD. Ann Pharmacother 2003;37:1247-55.

[28] Sin DD, McAlister FA, Man SF, Anthonisen NR. Contemporary management of chronic obstructive pulmonary disease: scientific review. JAMA 2003;290:2301-12.

[29] Mahler DA, Wire P, Horstman D, et al. Effectiveness of Fluticasone Propionate and Salmeterol Combination Delivered via the Diskus Device in the Treatment of Chronic Obstructive Pulmonary Disease. Am J Respir Crit Care Med 2002;166:1084-91.

[30] Barnes PJ. Inhaled corticosteroids are not beneficial in chronic obstructive pulmonary disease. Am J Respir Crit Care Med 2000;161:342-4, discussion 344.

[31] Calverley PM. Inhaled corticosteroids are beneficial in chronic obstructive pulmonary disease. Am J Respir Crit Care Med 2000;161:341-2, discussion 344. 
[32] van Schayck CP, van Grunsven PM, Dekhuijzen PN. Do patients with COPD benefit from treatment with inhaled corticosteroids? Eur Respir J 1996;9:1969-72.

[33] Weiner P, Weiner M, Rabner M, Waizman J, Magadle R, Zamir $D$. The response to inhaled and oral steroids in patients with stable chronic obstructive pulmonary disease. J Intern Med 1999;245:83-9.

[34] Paggiaro PL, Dahle R, Bakran I, Frith L, Hollingworth K, Efthimiou J. Multicentre randomised placebo-controlled trial of inhaled fluticasone propionate in patients with chronic obstructive pulmonary disease. International COPD Study Group. Lancet 1998;351:773-80.

[35] Pauwels RA, Lofdahl CG, Laitinen LA, et al. Longterm treatment with inhaled budesonide in persons with mild chronic obstructive pulmonary disease who continue smoking. European Respiratory Society Study on Chronic Obstructive Pulmonary Disease. N Engl J Med 1999;340:1948-53.

[36] Burge PS, Calverley PM, Jones PW, Spencer S, Anderson JA, Maslen TK. Randomised, double blind, placebo controlled study of fluticasone propionate in patients with moderate to severe chronic obstructive pulmonary disease: the ISOLDE trial. Br Med J 2000;320:1297-303.

[37] Calverley P, Pauwels R, Vestbo J, et al. Combined salmeterol and fluticasone in the treatment of chronic obstructive pulmonary disease: a randomised controlled trial. Lancet 2003;361:449-56.

[38] Calverley PM, Boonsawat W, Cseke Z, Zhong N, Peterson $\mathrm{S}$, Olsson $\mathrm{H}$. Maintenance therapy with budesonide and formoterol in chronic obstructive pulmonary disease. Eur Respir J 2003;22:912-9.

[39] Szafranski W, Cukier A, Ramirez A, et al. Efficacy and safety of budesonide/formoterol in the management of chranic obstructive pulmonary disease. Eur Respir J 200:;21:74 81.

[40] Sin DD, Wu L, Anderson J t t al. In aled corticosteroids anh mortality in cir hic pos ructive pulmonary discise. Tho ax 2005:60: $192 \%$

[41] Hanania NA, Darken P, Horst naa $D$, et al. The efficacy and safety of fluticasone propionate $250 \mathrm{mcg} /$ salmeterol $50 \mathrm{mcg}$ combined in the discus inhaler for the treatment of chronic obstrctive pulmonary disease. Chest 2003;124:83443.

[42] Dal Negro RW, Pomari C, Tognella S, Micheletto C. Salmeterol \& fluticasone $50 \mathrm{microg} / 250 \mathrm{microg}$ bid in combination provides a better long-term control than salmeterol 50 microg bid alone and placebo in COPD patients already treated with theophylline. Pulm Pharmacol Ther 2003;16:241-6.

[43] Vestbo J, Pauwels R, Anderson JA, Jones P, Calverley P. Early onset of effect of salmeterol and fluticasone propionate in chronic obstructive pulmonary disease. Thorax 2005;60:301-4.

[44] Wouters EF, Postma DS, Fokkens B, et al. Withdrawal of fluticasone propionate from combined salmeterol/fluticasone treatment in patients with COPD causes immediate and sustained disease deterioration: a randomised controlled trial. Thorax 2005;60:480-7.

[45] Donohue JF, Kalberg C, Emmett A, Merchant K, Knobil K. A short-term comparison of fluticasone propionate/salmeterol with ipratropium bromide/albuterol for the treatment of COPD. Treat Respir Med 2004;3:173-81.

[46] Make B, Hanania NA, ZuWallack R, et al. The efficacy and safety of inhaled fluticasone propionate/salmeterol compared with ipratropium/albuterol in the treatment of COPD. Clinical Therapeutics 2005;27(5):532-42.
[47] Jones PW, Quïrk F, Baveystock CM, Littlejohns P. A selfcomplete measure of health status for chronic airflow limitation. The St. George's Respiratory Questionnaire. Am Rev Respir Dis 1992;145:1321-7.

[48] Guyatt GH, Berman LB, Townsend M, Pugsley SO, Chambers LW. A measure of quality of life for clinical trials in chronic lung disease. Thorax 1987;42:773-8.

[49] Jaeschke R, Singer J, Guyatt GH. Measurement of health status. Ascertaining the minimal clinically important difference. Control Clin Trials 1989;10:407-15.

[50] Turato G, Zuin R, Saetta M. Pathogenesis and pathology of COPD. Respiration 2001;68:117-28.

[51] Groenewegen KH, Schols AM, Wouters EF. Mortality and mortality-related factors after hospitalization for acute exacerbation of COPD. Chest 2003;124:459-67.

[52] Patil SP, Krishnan JA, Lechtzin N, Diette GB. Inhospital mortality following acute exacerbations of chronic obstructive pulmonary disease. Arch Intern Med 2003;163:1180-6.

[53] Seneff MG, Wagner DP, Wagner RP, Zimmerman JE, Knaus WA. Hospital and 1-year survival of patients admitted to intensive care units with acute exacerbation of chronic obstructive pulmonary disease. JAMA 1995;274: 1855-7.

[54] Donaldson GC, Seemungal TA, Bhowmik A, Wedzicha JA. Relationship between exacerbation frequency and lung function decline in chronic obstructive pulmonary disease. Thorax 2002; 57:847-52.

[55] GOLD. Global strategy for the diagnosis management and prevention of COPD: 2003 lipdat?. Eur Respir J 2003;22:1-2.

[56] Sin DD, Tu N Nolited corticosteroids and the risk of mo cality and readmission in elderly patients with chronic obstructive pülnonary disease. Am J Respir Crit Care Med $2001 \cdot 104: 580-4=0$

[571 Sriand JB, Vestbo J, Pride NB, Kiri V, Maden C, Maier WC. Survival in COPD patients after regular use of fluticasone propionate and salmeterol in general practice. Eur Respir J 2002;20:819-25.

[58] Soriano JB, Kiri VA, Pride NB, Vestbo J. Inhaled corticosteroids with/without long-acting beta-agonists reduce the risk of rehospitalization and death in COPD patients. Am J Respir Med 2003;2:67-74.

[59] Vestbo J. The TORCH (towards a revolution in COPD health) survival study protocol. Eur Respir J 2004;24:206-10.

[60] Lung Health Study Research Group. Effect of inhaled triamcinolone on the decline in pulmonary function in chronic obstructive pulmonary disease. N Engl J Med 2000;343:1902-9.

[61] Hubbard RB, Smith CJ, Smeeth L, Harrison TW, Tattersfield AE. Inhaled corticosteroids and hip fracture: a populationbased case-control study. Am J Respir Crit Care Med 2002;166:1563-6.

[62] Halpern MT, Schmier JK, Van Kerkhove MD, Watkins $M$, Kalberg CJ. Impact of long-term inhaled corticosteroid therapy on bone mineral density: results of a meta-analysis. Ann Allergy Asthma Immunol 2004;92:201-7, quiz 207-8, 267.

[63] Johannes CB, Schneider GA, Dube TJ, Alfredson TD, Davis $\mathrm{KJ}$, Walker $A M$. The risk of nonvertebral fracture related to inhaled corticosteroid exposure among adults with chronic respiratory disease. Chest 2005;127:89-97.

[64] Suissa S, Baltzan M, Kremer R, Ernst P. Inhaled and nasal corticosteroid use and the risk of fracture. Am J Respir Crit Care Med 2004;169:83-8.

[65] Malolepszy J, Boszormenyi Nagy G, Selroos O, Larsso P, Brander R. Safety of formoterol Turbuhaler at cumulative 
dose of 90 microg in patients with acute bronchial obstruction. Eur Respir J 2001;18:928-34.

[66] Kempsford R, Handel M, Mehta R, De Silva M, Daley-Yates P. Comparison of the systemic pharmacodynamic effects and pharmacokinetics of salmeterol delivered by CFC propellant and non-CFC propellant metered dose inhalers in healthy subjects. Respir Med 2005;99(Suppl A):S11-9.

[67] Fenton C, Keating GM. Inhaled salmeterol/fluticasone propionate: a review of its use in chronic obstructive pulmonary disease. Drugs 2004;64:1975-96.

Available online at www.sciencedirect.com

science

\section{Available online at http://www.thepcrj.com}

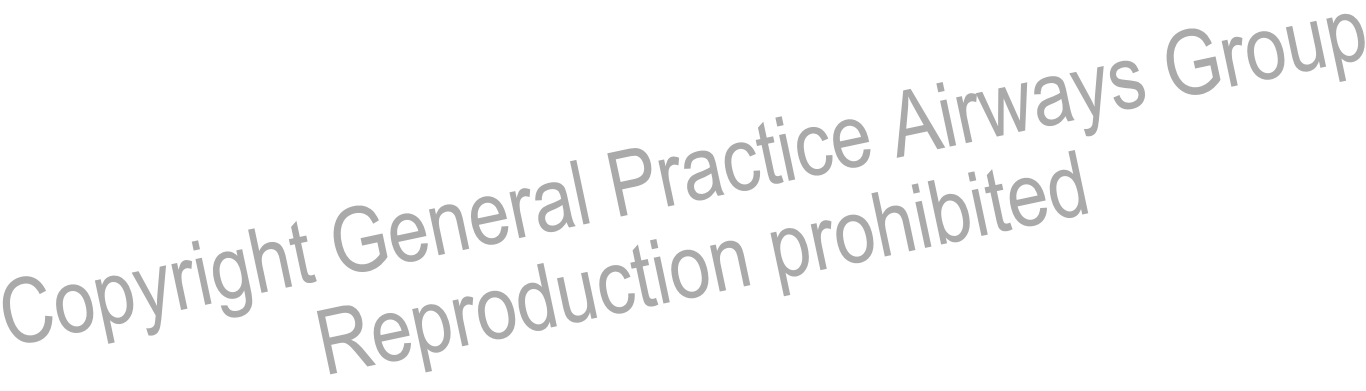

